УДК 658.382(075.8)

\title{
NORMATIVE REGULATION OF EMPLOYMENT OF DISTANTLY LEARNING STUDENTS
}

\author{
L. E. Piskunova, T. O. Zubok, M. O. Shkapa
}

National University of Life and Environmental Sciences of Ukraine. Ukraine.

Speciality of article: 275 - transport technologies (by road).

Corresponding author: tanyzubok@gmail.com

Article history: Received-January 2020, Accepted-April 2020.

Bibl. 22, fig. 0, tabl. 2.

Abstract. Proper paperwork, observance of the right to preferential working conditions, defined by the current legislation, is the key to successful acquisition of a properly educated employee. While studying distantly and working, students need to know not only their responsibilities but also their rights.

Let us pay attention to the normative regulation of employment of distantly educating students studying at the National University of Life and Environmental Sciences of Ukraine.

In practice, the most common questions are how chiefs treat students of different forms of education - in their opinion, this causes additional costs for different vacations, distracts the employee from work, and when the employee finishes studying, he or she will require to give him a new job in accordance with the education obtained; benefits, because studying (at a distance or evening department of a university) gives the employee a number of benefits, which the company has no right to refuse. Such benefits include, in particular, extra paid holidays in connection with studies in secondary, vocational, higher institutions, educational institutions of postgraduate education and vacation without payment. Is industrial training possible for staff? In the labor legislation of Ukraine, in this sense, provided a number of benefits for workers who improve their qualification level without interruption from production. Thus, Articles 201 and 204 of the Labor Code stipulate that personnel training in this case occure using the expense of the enterprise and during working hours. Is there a fare for the place of study? All employees who reside and work outside the location of the educational institution are entitled to the fare. The employer pays for employees who study at higher education institutions with evening and distance education, to get to the location of the educational institution and back once a year.

Key words: Code of Labor Laws of Ukraine, State Department for Supervision of Labor Legislation Compliance, Instructions on the procedure of keeping employment records, labor legislation, work under employment contract, employment record, part-time, monetary expression, correspondence department.

\section{Introduction}

The purpose of our work is to overview some of the most common because of which distantly learning students have so many questions. In the previous articles we raised questions about the normative aspects of employment of day studies students, namely: legality of employment; keeping work books; labor law; work under an employment contract; work of minors, etc.

\section{Formulation of problem}

While studying distantly and working along the way, students need to know not only their responsibilities but also their rights. Let us pay attention to the normative regulation of employment of part-time students studying at the National University of Life and Environmental Sciences of Ukraine (here in after NULES).

\section{Analysis of recent research results}

Most young people today work unofficially, considering this to be superfluous formalities.

But if your job is related to a specialty, the first entry in the employment record will confirm the experience that was gained. In addition, in this way you begin to count down your seniority, which will continue to accrue a pension.

It sounds good, but in practice, employers do not rush to formalize relationships with students both inpatient and correspondence.

Proper registration of documents, observance of the right to preferential working conditions, defined by the current legislation, is the key to successful acquisition of a properly educated employee.

It should be noted here that it is not always a cursory reading of the provisions of the regulations that makes it possible to understand how the employer should act in securing the employee's right to education. 


\section{Purpose of research}

The purpose of this work is to consider some of the most common situations that, in practice, most often raise questions by students of distance learning.

\section{Results of research}

So, let's look at some of the most common situations that often raise questions in practice.

It's not a secret that heading don't approve so much hiring day and distantly learning students, because, in their opinion, this entails additional costs for various vacations, distracts the employee from work, and when the employee completes his or her training, he or she will require a new job to be given to him / her in accordance with the received education. Such managers do not quite understand that in the future they will have a competent, familiar with the features of production, a young but already experienced worker.
There is no doubt that the place of the student's main work is the enterprise where he works. And studying (distantly or evening classes) gives the employee a number of benefits, which the company has no right to refuse. Such benefits include, inter alia, additional paid vacation in connection with studies in secondary, vocational, higher education and postgraduate education and vacation without preservation of payment.

Firstly, let's look at the terms of the extra paid holidays. The right to have such vacations is only granted to employees who successfully study without leaving the production in higher educational establishments with evening and distance forms of studying for the period of preparatory classes, performance of laboratory work, taking tests and examinations, preparation and defense of the diploma project (work) (Art. 216 of the Labor Code and Article 15 of the Law of Ukraine " About vacations " of November 15, 1996 No. 504/96-BP). In accordance with Article 217 of the Labor Code, the average wage is maintained for the employees at their principal place of work during such leave.

Table 1. Duration of vacation by type and form of study.

\begin{tabular}{|c|c|c|c|c|}
\hline Type of studying load & Course & Form of studying & $\begin{array}{c}\text { The level of } \\
\text { accreditation of } \\
\text { the educational } \\
\text { institution }\end{array}$ & The duration of vacation \\
\hline \multirow{6}{*}{$\begin{array}{l}\text { For the period of instructional } \\
\text { classes, laboratory work, } \\
\text { passing tests and exams }\end{array}$} & \multirow[t]{2}{*}{ I, II } & \multirow[t]{2}{*}{ Evening } & I, II & 10 calendar days \\
\hline & & & III, IV & 20 calendar days \\
\hline & \multirow[t]{4}{*}{$\begin{array}{l}\text { III and } \\
\text { next }\end{array}$} & $\begin{array}{l}\text { External form of } \\
\text { education }\end{array}$ & $\begin{array}{l}\text { Regardless of the } \\
\text { course }\end{array}$ & 30 calendar days \\
\hline & & \multirow[t]{2}{*}{ Evening } & I, II & 20 calendar days \\
\hline & & & III, IV & 30 calendar days \\
\hline & & $\begin{array}{l}\text { External form of } \\
\text { education }\end{array}$ & $\begin{array}{l}\text { Regardless of the } \\
\text { course }\end{array}$ & 40 calendar days \\
\hline For the period of state exams & & $\begin{array}{l}\text { External and } \\
\text { evening }\end{array}$ & $\begin{array}{l}\text { Regardless of the } \\
\text { course }\end{array}$ & 30 calendar days \\
\hline \multirow{2}{*}{$\begin{array}{l}\text { For the period of preparation } \\
\text { and protection of the state } \\
\text { project }\end{array}$} & & \multirow{2}{*}{$\begin{array}{l}\text { External and } \\
\text { evening }\end{array}$} & I, II & 2 months \\
\hline & & & III, IV & 4 months \\
\hline
\end{tabular}

The criterion of "success" is not set by law, so studying will be considered successful if the employee does not have poor grades. But in any case, paid leave to eliminate academic debt is not granted, and employees who fail in time or in completion the curriculum, additional leave is granted at the discretion of the enterprise and at the expense of the employee.

The reason for giving an employee additional paid leave in connection with studying is:

- a document (certificate-call for a session), issued by the educational institution in which the employee receives education. Methodists of distance education of NULES of Ukraine prepare documents, which state the period during which the student must participate in the laboratory examination (examination) session, and provide information about his success;

- employee's application for additional leave in connection with studying.
The duration of additional paid leave is established by the Article 216 of the Labor Code and the Article 15 of the Law of Ukraine "About vacations". It depends on the form of education, the type of workload, the course at which the person studies, and the level of accreditation of the educational institution.

For ease of use, information on the duration of vacation by type of studying, we present in Table 1 .

For employees studying in higher education institutions with evening and External forms of education, where the educational process has its own peculiarities, the law may set a different duration of study vacation.

Thus, on the basis of the resolution of the Cabinet of Ministers of Ukraine of June 28, 1997 №634 "On approval of the Procedure, duration and conditions of granting annual vacations to employees, who are studying in higher education institutions with evening and distance learning form of studying, where the educational process 
has its own characteristics", exception has only that vacation, which is provided by the Article 15 of the Law of Ukraine "On Vacation", employees, who successfully study in higher educational institutions of all levels of accreditation with evening and extramural forms of education in the areas of training, are also granted annual vacation by industry (Table 2 ).

Table 2. Duration of additional vacation.

\begin{tabular}{|l|l|l|}
\hline \multicolumn{1}{|c|}{ Training direction } & \multicolumn{2}{c|}{ Duration of vacation } \\
\cline { 2 - 3 } & \multicolumn{1}{|c|}{ Paid } & \multicolumn{1}{c|}{ Unpaid } \\
\hline $\begin{array}{l}\text { Culture (folk art) musical art (piano, organ, } \\
\text { orchestral strings, wind, percussion, singing, } \\
\text { conducting, pop music) }\end{array}$ & 10 calendar days & 10 calendar days \\
\hline $\begin{array}{l}\text { Theatrical art (acting, directing, choreography) } \\
\text { film and television (film and television } \\
\text { directing) }\end{array}$ & 20 calendar days & 10 calendar days \\
\hline Philology (language and literature) & - & 10 calendar days \\
\hline
\end{tabular}

These vacations are granted, respectively, for the period of instructional classes, laboratory work, tests and exams, state exams, preparation and defense of the diploma project (work). Higher education institutions have the right, if necessary, to redistribute additional vacation between courses within the total duration of the educational process.

In practice, the duration of additional leave granted to an employee in connection with training, usually corresponds to the duration of the laboratory-examination (examination) session established by the curriculum of the higher education institution, which is confirmed by the certificate-call for the session, so the duration of such leave may be less than it is provided by the Article 216 of the Labor Code and Article 15 of the Law of Ukraine "On Vacation". In this case, drawing up an order about giving an additional study vacation, it is necessary to determine its duration based on the number of days specified in the notification for a session.

Additional paid study vacation is granted to the employee for the entire period of the session and does not depend on the term of his continuous work in the first year of work at the enterprise. In addition, according to paragraph 4 of Article 11 of the Law of Ukraine "On Vacation", if the annual leave coincides with the leave in connection with studies, such annual leave may be postponed to another period or, at the request of the employee, extended.

Employees who successfully study in the evening departments of vocational schools are provided with additional paid vacation to prepare for exams and taking them for a total of 35 calendar days during the school year. The application of this article in practice is in fact limited to granting such vacation to employees who acquire new professions in the areas of work of enterprises and, with some exceptions, at the initiative of the employer.

Additional paid leave is also granted to employees, who are admitted to the entrance examinations to graduate school with or without separation from work, to prepare and take exams once a year at the rate of 10 calendar days for each exam.

Workers who study full-time in postgraduate studies and successfully complete an individual training plan are provided with additional paid leave for 30 calendar days and, if they wish, for four years of study - one day off per week with a payment of 50 percent. from the average salary of the employee.

Article 25 of the Law of Ukraine "On Vacation" defines the duration of vacation without payment, which is provided to the employee in a mandatory manner:

- employees admitted to entrance exams to higher education institutions - for a period of 15 calendar days without taking into account the time required to travel to the location of the educational institution and back. This vacation is granted regardless of the level of accreditation of the educational institution. The basis for its giving is the application of the employee and the notification of the educational institution about the admission to the entrance exams;

- employees admitted to the entrance examinations for postgraduate studies with or without on-the-job work, as well as employees who study full-time in postgraduate studies and successfully complete an individual training plan - the duration required to travel to the location of the higher education institution or institution of science and ba ck.

In addition, postgraduate students, who are studying on-the-job, are provided with one day off per week without pay during the fourth year of study, if they wish so.

Separately, we would like to dwell on the industrial training of staff. The labor legislation of Ukraine in this regard provides a number of benefits for employees who increase their skills on-the-job. Thus, Articles 201 and 204 of the Labor Code stipulate that staff training in this case takes place at the expense of the enterprise and during working hours.

However, due to the large migration of labor resources in Ukraine at the moment, it is unprofitable for the owner to invest in staff training at the expense of the company, because the specialist after training can go to work for a competitor. To get out of this situation, the employer often tries to select already trained staff by someone and somehow. So, no one wants to be a "smithy of workers" for other companies. Thus, the head of the enterprise continues to spend money in vain (and possibly lose its regular customers), because a new employee, even a trained one, needs some time for internal adaptation to the enterprise and to the production process itself. 
In order to avoid any unpleasant situations, the employer must still "grow" educated and professionally competent staff at the company, taking into account, of course, the requirements of current labor legislation of Ukraine.

However, we should not forget about another point. The legislation of Ukraine does not prohibit the employer before the start of staff training to enter into a civil contract with each employee that the training of new professions (development of new technologies, training, etc.) will be carried out at the expense of the company with the provision of all benefits and guarantees Ukraine, however, after completing the training course, the employee will be required to work at the company for a certain period of time (six months, a year, two or other terms - depending on the amount of money, invested in his studies). In the case of early dismissal of an employee (regardless of the reasons for dismissal, except for conscription for military or alternative service, election to an elected position or death of the employee), the latter will be obliged to reimburse the cost of training based on time already worked. It will be easy for the economist or accountant to calculate the period for which the tuition fee must be reimbursed.

Thus, a well-written contract, which provides for the rights and obligations of the parties (employer and employee), will allow:

a) the employee:

- increase their professional and qualification level;

- have certain prospects, stable work and earnings;

- be properly motivated for the purpose and objectives of the enterprise;

- derive certain personal benefits from it;

b) the owner:

- have competent, trained staff at the enterprise;

- be able to avoid aimless and constant investment in the training of employees who change frequently;

- sharply reduce staff turnover;

- increase productivity and quality of work;

- improve the quality of products or services;

- to raise the image of the company in the region, demonstrating its stability and compliance with the law, as well as the prospects and professionalism of its employees, which is also probably an important factor in successful work.

The labor legislation of Ukraine provides also other benefits for employees who combine work with training. Thus, employees who study in the last years of higher education institutions, during the ten academic months before the start of the diploma project (work) or state exams are given a weekly, with a six-day working week, one day off to prepare for classes with payment in in the amount of 50 percent of the received salary, but not lower than the minimum salary. During a five-day work week, the number of days off varies depending on the duration of the work shift, provided that the total number of hours off is maintained.

During the ten academic months before the start of the diploma project (work) or passing the state exams, employees may, at their request, be provided with one or two additional days off per week without pay.

All employees who do not live and work outside the location of the educational institution have the right to have the paid travel. The employer pays employees who study in higher education institutions with evening and correspondence forms of education, travel to the location of the educational institution and back once a year for tutoring, for laboratory work and tests and exams - in the amount of 50 percent of the fare ( ie one-way fare). It should be noted that the Labor Code does not set restrictions on the type (class) of transport for which benefits are provided. In NULES, sessions with planned disciplines are composed in such a way that in one session students take disciplines, show their level of knowledge and listen to instructive lectures, receive independent assignments in subjects for the next session.

The same amount is used to pay for the preparation and defense of a diploma project (work) or to pass state exams.

\section{Conclusions}

1. As you can see, the number of benefits for employees who combine work with training is quite significant. But in practice not all of them are used. Modern forms of organization of the educational process in educational institutions allow the employee to receive education in his spare time (evening or weekends), so the employer in some cases may not even know about the employee's training.

2. In any case, an employee who intends to get an education or training and does not find understanding and support from the employer, should be aware that in today's labor market chance to win the competition has only a highly qualified specialist with experience and quality education. So learn by working.

3. And the employer, despite the number of benefits he has to provide to the employee, must remember that an employee who has become a specialist thanks to the company will work hard, willing to contribute to the prosperity of the company.

\section{References}

1. The Law of Ukraine "On Occupational Safety" in the wording of November 21, 2002.

2. The Law of Ukraine "On Compulsory State Social Insurance against Accident at Work and Occupational Disease that Caused Disability".

3. Legislation of Ukraine on labor protection (a collection of normative documents., $4 \mathrm{t}$. - $\mathrm{K}$.: State Committee of Ukraine for Supervision of Labor Protection, Osnova, 1995.

4. The Law of Ukraine "On Education" No. 1060XII of 23.05.1991 (subparagraph 14, paragraph 1, Article 51) and the Law of Ukraine "On Higher Education" dated July 1, 2014, No. 1556-VII (paragraph 3 of clause 1 Article 62).

5. Law of Ukraine "On Employment of the Population" of 1 March 1991 No. 803-XII.

6. Article 15 of the Law of Ukraine "On Vacations" dated November 15, 1996 No. 504/96-VR).

7. The Code of Labor Laws of Ukraine (Revision of 10.11.2018, basis -2542-VIII). 
(Article 2, Part 2 of Article 24, Articles 38, 39, 40, Part 1, Article 48, Article 50, Article 51, Part 1, Article 56, Article 94, Article 187- 200; st.201-204;) st.216-217; p.6 pp. 1 pp. 232; Part 6 of the Art. 235,238.

8. Art. 1 3У "About payment of labor" dated March 24, 1995, № 108/95-BP).

Part 1 of Art. 4 lesson № 5067-VI

9. pp. 7 clause 1 of Art. 1 Law of Ukraine "On Employment of the Population" dated 05.07.2012 No. 5067-VI (hereinafter - the Law № 5067-VI).

10. Letter of the Ministry of Social Policy of 05.05.2015 № 198/06 / 186-15.

11. Letter of the Ministry of Social Policy of Ukraine dated July 25, 2014 № 301/13 / 116-14.

12. Letter from the State Department for Supervision of Compliance with the Labor Law of August 8, 2002, No. 010-777.

13. Clause 1.4. Instruction on the procedure for conducting work books of workers (approved by the order of the Ministry of Labor of Ukraine, Ministry of Justice of Ukraine, Ministry of Social Protection of the Population of Ukraine dated July 29, 1993 No. 58).

14. Letter from the State Department for Supervision of Compliance with the Labor Law of August 20, 2003 No. 013-1229-22.

15. Resolution of the Plenary Session of the Supreme Court of Ukraine "On the Practice of the Application by the Courts of Labor Payments Legislation" of December 24, 1999, No. 13.

16. Part 3, Clause 14 of the Resolution of the Supreme Court of Ukraine "On the Practice of the Use by the Courts of the Law on Remuneration of Work" of December 24, 1999, No. 13.

17. Resolution of the Cabinet of Ministers of Ukraine dated 28 June 1997. No. 634 "On Approval of the Procedure, Duration and Conditions for the Provision of Annual Vacations for Workers Studying at Higher Educational Institutions with Evening and Extramural Forms of Education, where the educational process has its own peculiarities".

18. State sanitary norms and rules "Hygienic classification of labor on the indicators of harmfulness and danger factors of the production environment, the severity and intensity of the labor process", approved by the order of the Ministry of Health of Ukraine from 08.04.2014 number 248.

19. Order of the Ministry of Health of Ukraine of 25.05.2006 № 319.

20. Order of the Ministry of Labor and Social Policy of Ukraine dated March 23, 2001 №122.

21. The procedure for the certification of workplaces under the terms of work, approved by the Cabinet of Ministers of Ukraine from 01.08.92, No. 442.

22. Fundamentals of labor protection: the textbook. Zaporozhets O.I .; ed. prof. OI Zaporozhets. Kyiv: Publishing Center of the Central Library, 2018. 264.

\section{Список літератури}

1. The Law of Ukraine "On Occupational Safety" in the wording of November 21, 2002
2. The Law of Ukraine "On Compulsory State Social Insurance against Accident at Work and Occupational Disease that Caused Disability".

3. Legislation of Ukraine on labor protection (a collection of normative documents., 4 t. - K .: State Committee of Ukraine for Supervision of Labor Protection, Osnova, 1995.

4. The Law of Ukraine "On Education" No. 1060XII of 23.05.1991 (subparagraph 14, paragraph 1, Article 51) and the Law of Ukraine "On Higher Education" dated July 1, 2014, No. 1556-VII (paragraph 3 of clause 1 Article 62)

5. Law of Ukraine "On Employment of the Population" of 1 March 1991 No. 803-XII

6. Article 15 of the Law of Ukraine "On Vacations" dated November 15, 1996 No. 504/96-VR).

7. The Code of Labor Laws of Ukraine (Revision of 10.11.2018, basis -2542-VIII)

(Article 2, Part 2 of Article 24, Articles 38, 39, 40, Part 1, Article 48, Article 50, Article 51, Part 1, Article 56, Article 94, Article 187- 200; st.201-204;) st.216-217; p.6 pp. 1 pp. 232; Part 6 of the Art. 235,238.

8. Art. 1 3У "About payment of labor" dated March 24, 1995, № 108/95-BP).

Part 1 of Art. 4 lesson № 5067-VI

9. pp. 7 clause 1 of Art. 1 Law of Ukraine "On Employment of the Population" dated 05.07.2012 No. 5067-VI (hereinafter - the Law № 5067-VI)

10. Letter of the Ministry of Social Policy of 05.05.2015 № 198/06 / 186-15.

11. Letter of the Ministry of Social Policy of Ukraine dated July 25, 2014 № 301/13 / 116-14

12. Letter from the State Department for Supervision of Compliance with the Labor Law of August 8, 2002, No. 010-777.

13. Clause 1.4. Instruction on the procedure for conducting work books of workers (approved by the order of the Ministry of Labor of Ukraine, Ministry of Justice of Ukraine, Ministry of Social Protection of the Population of Ukraine dated July 29, 1993 No. 58)

14. Letter from the State Department for Supervision of Compliance with the Labor Law of August 20, 2003 No. 013-1229-22

15. Resolution of the Plenary Session of the Supreme Court of Ukraine "On the Practice of the Application by the Courts of Labor Payments Legislation" of December 24, 1999, No. 13.

16. Part 3, Clause 14 of the Resolution of the Supreme Court of Ukraine "On the Practice of the Use by the Courts of the Law on Remuneration of Work" of December 24, 1999, No. 13.

17. Resolution of the Cabinet of Ministers of Ukraine dated 28 June 1997. No. 634 "On Approval of the Procedure, Duration and Conditions for the Provision of Annual Vacations for Workers Studying at Higher Educational Institutions with Evening and Extramural Forms of Education, where the educational process has its own peculiarities".

18. State sanitary norms and rules "Hygienic classification of labor on the indicators of harmfulness and danger factors of the production environment, the severity and intensity of the labor process", approved by the order of the Ministry of Health of Ukraine from 08.04.2014 number 248 . 
19. Order of the Ministry of Health of Ukraine of 25.05.2006 № 319 .

20. Order of the Ministry of Labor and Social Policy of Ukraine dated March 23, 2001 №122

21. The procedure for the certification of workplaces under the terms of work, approved by the Cabinet of Ministers of Ukraine from 01.08.92, No. 442.

22. Fundamentals of labor protection: the textbook. Zaporozhets O.I .; ed. prof. OI Zaporozhets - Kyiv: Publishing Center of the Central Library, 2018. 264 p.

\section{НОРМАТИВНЕ РЕГУЛЮВАННЯ}

ПРАЦЕВЛАШТУВАННЯ СТУДЕНТІВ, ЩО

НАВЧАЮТЬСЯ НА ЗАОЧНОМУ ВІДДІЛЕННІ

Л. Е. Піскунова, Т. О. Зубок, М. О. Шкапа

Анотація. Належне оформлення документів, дотримання права на пільгові умови праці, визначені чинним законодавством, $\epsilon$ запорукою успішного набуття належно освіченого працівника. Навчаючись віддалено і працюючи, студентам потрібно знати не тільки свої обов'язки, але і свої права.

Звернемо увагу на нормативне регулювання зайнятості студентів, які навчаються на дистанційному рівні в Національному університеті біоресурсів та природокористування України.

На практиці найпоширеніші питання полягають у тому, як начальники ставляться до студентів різних форм навчання - на їхню думку, це спричиняе додаткові витрати на різні канікули, відволікає працівника від роботи, а коли працівник закінчить навчання, йому потрібно буде дати йому нову роботу відповідно до здобутої освіти; вигоди, оскільки навчання (на дистанційному або вечірньому відділенні університету) дає працівникові ряд пільг, від яких компанія не має права відмовляти. До таких пільг належать, зокрема, додаткові оплачувані відпустки у зв'язку 3 навчанням у середніх, професійно-технічних, вищих закладах, навчальних закладах післядипломної освіти та відпустки без оплати. Чи можливе виробниче навчання персоналу? У законодавстві про працю України в цьому сенсі передбачено ряд пільг для працівників, які підвищують свій кваліфікаційний рівень без відриву від виробництва. Так, статтями 201 та 204 КЗПП визначено, що навчання персоналу в цьому випадку відбувається за рахунок коштів підприємства та в робочий час. Чи $є$ тариф на місце навчання? Усі працівники, які проживають та працюють за межами місцезнаходження навчального закладу, мають право на проїзд. Роботодавець оплачує працівникам, які навчаються у вищих навчальних закладах з вечірньою та дистанційною освітою, потрапляти до місця навчання та назад раз на рік.

Ключові слова: Кодекс законів про працю України, Державний департамент нагляду за додержанням законодавства про працю, Інструкції про порядок ведення трудових книжок, трудове законодавство, робота за трудовим договором, трудова книжка, сумісництво, грошовий вираз, заочне відділення.
НОРМАТИВНОЕ РЕГУЛИРОВАНИЕ

РАБОТОУСТРОЙСТВА СТУДЕНТОВ, КОТОРЫЕ

УЧАТЬСЯ НА ЗАОЧНОМ ОТДЕЛЕНИИ

Л. Э. Пискунова, Т. А. Зубок, М. О. Шкапа

Аннотация. Правильное оформление документов, соблюдение права на льготные условия труда, определенные действующим законодательством, является залогом успешного приобретения должным образом образованного работника. При обучении на расстоянии и работе ученики должны знать не только свои обязанности, но и свои права.

Обратим внимание на нормативное регулирование трудоустройства дистанционно обучающихся студентов, обучающихся в Национальном университете естественных и общественных наук Украины.

На практике наиболее распространенными вопросами являются то, как начальники относятся к учащимся разных форм обучения - по их мнению, это вызывает дополнительные расходы на разные каникулы, отвлекает работника от работы, а когда работник заканчивает учебу, ему или ей потребуется дать ему новая работа в соответствии с полученным образованием; льготы, потому что обучение (на заочном или вечернем отделении университета) дает работнику ряд льгот, от которых компания не имеет права отказываться. К таким льготам относятся, в частности, дополнительные оплачиваемые отпуска в связи с обучением в средних, профессиональных, высших учебных заведениях, учебных заведениях последипломного образования и оплачиваемых отпусках. Возможно ли производственное обучение персонала? В трудовом законодательстве Украины в этом смысле предусмотрен ряд льгот для работников, которые повышают свой уровень квалификации без отрыва от производства. Так, статьи 201 и 204 Трудового кодекса предусматривают, что обучение персонала в этом случае происходит за счет средств предприятия и в рабочее время. Есть ли плата за место учебы? Все сотрудники, которые проживают и работают за пределами учебного заведения, имеют право на оплату проезда. Работодатель оплачивает сотрудникам, которые учатся в высших учебных заведениях с вечерним и дистанционным образованием, чтобы добраться до места нахождения учебного заведения и обратно один раз в год.

Ключевые слова: Кодекс законов о труде Украины, Государственный департамент надзора за соблюдением законодательства о труде, Инструкции о порядке ведения трудовых книжек, трудовое законодательство, работа по трудовому договору, трудовая книжка, совместительство, денежное выражение, заочное отделение.

Л. Е. Піскунова ORCID 0000-0002-6351-0660.

T. О. Зубок ORCID 0000-0001-7559-0859.

М. О. Шкапа ORCID 0000-0003-3607-6712. 